\title{
Performance Assessment, Genetic Variability, Heritability, Genetic Advance and Correlation Coefficient Analysis for Yield and Some Agro -Morphological Traits in Faba Bean (Vicia faba L.) Genotypes in the Northern State, Sudan
}

\author{
Fatih E.A. Hamza* \\ Merowe Research Station, Agricultural Research Corporation, \\ P. O. Box 126 Wad Medani, Sudan \\ *Corresponding author
}

\begin{tabular}{|c|}
\hline Keywords \\
\hline $\begin{array}{l}\text { Faba bean, Genetic } \\
\text { variability, } \\
\text { Heritability, } \\
\text { Correlation, Seed } \\
\text { yield. }\end{array}$ \\
\hline Article Info \\
\hline $\begin{array}{l}\text { Accepted: } \\
\text { 12 September } 2017 \\
\text { Available Online: } \\
10 \text { November } 2017\end{array}$ \\
\hline
\end{tabular}

\section{Introduction}

Faba bean (Vicia faba L.) $(2 \mathrm{n}=12)$, which is also known as broad bean, horse bean or field bean, belongs to the family leguminaceae. Its origin is still argued (Duc, 1997), but geographically it was the Near East. According to seed size faba bean is divided into three main types: major type, which is characterized by large seeds and originated in South Mediterranean countries and China; equina or medium-seed type, which is originated in Middle East and North Africa; and minor or smallest-seed type, which is originated in Ethiopia (Witcombe, 1981). The main producing countries for Faba bean (Vicia faba L.), depending on acreage are Morocco, Tunisia, Algeria, U.K, Egypt, Ethiopia, China, Australia and Sudan (FAO, 2000). Faba bean is the most important food legume in the Sudan. It constitutes the main dish on the breakfast and dinner tables for a 
large sector of the population, especially low income groups in the urban areas. In addition, it contributes to soil fertility through biological N2-fixation. The crop is also an important source of income for farmers in northern Sudan. In some years the production falls below the demand and, thus, like in 1994, a sizeable amount needs to be imported to bridge the gap. The area under faba bean cultivation has increased from about 7,450 ha in 1965 to about 30,000 ha in the 1994/95 season. The main production zone of the crop is the Northern State where more than $70 \%$ of crop is produced, and the Nile State which produces about $20 \%$ of the crop. Small amounts are produced in Khartoum State, central Sudan and Jebel Marra area in western Sudan (Salih et al., 1995).

The genetic improvement of crop desired traits depends on the nature and magnitude of genetic variability and interactions involved in the inheritance of these traits which can be estimated using experimental design techniques. Many researchers studied heritability for seed yield, yield components and the other agro-morphological traits in faba bean. Seed yield is a complex trait that is quantitatively inherited with low heritability value (Bond, 1966).

The low heritability and consequent limited genetic advance for yield in response to selection had led many scientists to search for characters which are associated with yield but which are more highly heritable (De Pace, 1979). Among secondary yield component significant positive correlation between seed yield and its component was reported in number of branches per plant by (Sindhu et al., 1985). Significant negative correlation was reported between seed yield and plant height by (Abdelmula, 2002). Also, significant positive correlation was observed between seed yield and maturity, (Abdelmula, 2002).
The present study aimed to estimate the genetic variability, heritability and genetic advance for yield and yield components of four faba bean genotypes and correlation coefficients between seed yield and other traits were also investigated.

\section{Materials and Methods}

\section{Experimental site}

The data of this research experiment were collected from a study conducted over three consecutive seasons $(2013 / 14,2014 / 15$ and 2015/16 during the winter season, at Merowe (The experimental farm of Merowe research station, Northern state of Sudan), which is located (Latitude: $18^{\circ} 27^{\prime} 0^{\prime \prime} \mathrm{N}$, Longitude: 31 49' 59" E, Elevation: 258 meter.

\section{Genetic materials}

The genetic material used in this study comprised a total of 4 faba bean genotypes, which were selected from the national legume breeding program of the Agricultural Research Corporation (ARC), Sudan. Three genotypes are advanced breeding lines and one released faba bean variety; SM - L was included as check. The pedigree of the four faba bean genotypes used in the study were shown in Table 1.

\section{Cultural practices}

\section{Land preparation and sowing}

The field prepared by disk ploughing, harrowing and leveling. After two days from leveling, the land was ridged. Sowing was on both sides of the ridge at a rate of two seeds per hole with intra row spacing of $20 \mathrm{~cm}$ between holes. The plot size was consisted of 5 ridges, $5 \mathrm{~m}$ long spaced $0.6 \mathrm{~m}$. The sowing dates of the three seasons were usually within the third week of November. The plants were 
irrigated equally at $12-14$ days interval. The crop took a total of 10 irrigations during the growing period. Nitrogen was added as urea $(46 \%)$ at a rate of $43 \mathrm{~kg} \mathrm{~N} / \mathrm{ha}$ in the $3^{\text {rd }}$ week from sowing. Weeds populations were kept to minimum by hand removal during the first month from sowing. In the first and third season, the crop was sprayed with folimat against the aphid (Aphis fabae sp.), when it appeared in the field. Seed yield was assessed from a net area of $9 \mathrm{~m}^{2}$.

\section{Experimental layout}

The experiments were arranged in a randomized complete block design with three replications.

\section{Parameters measures}

During the three seasons, observations were taken on ten plants randomly selected in a plot. Data were recorded on the following vegetative and reproductive characters:

Days to $50 \%$ flowering: it was recorded as the number of days from sowing to the date when $50 \%$ of the plants in a plot bore at least one flower.

Days to $90 \%$ maturity: it was estimated as days from sowing to the date when $90 \%$ of the leaves in the row turned yellow and green pods became black.

Plant height: it was measured from ground level to the top of the plant at maturity. An average of ten plants was recorded in centimeters $(\mathrm{cm})$.

Number of pods per plant: pods of 5 randomly taken plants were counted to estimate number of pods per plant.

Number of seeds per pod: it was calculated by dividing the total number of seeds per plant (of the sample) by the total number of pods per plant.

100 - Seed weight (g) Hundred seeds were taken randomly from each plot and weighed using a sensitive balance namely, Sartorius.

Seed yield $\left(\mathrm{kg} \mathrm{ha}^{-1}\right)$ : At maturity, plots were harvested by hand and seed yield $\mathrm{kg} \mathrm{ha}^{-1}$ was determined.

\section{Statistical analysis}

Separate ANOVA in each environment was performed for grain yield and related traits before running the combined analysis.

The mean separation was done using Duncan's Multiple Range Test (DMRT) for the different characters collected from the field experiments at the level of $p \leq 0.05$. The correlation analysis was worked out according to the methods described by (Dewey and Lu, 1959) and (Falconer, 1964).

\section{Phenotypic and genotypic variability}

The variability present in the genotypes was estimated by simple measure, namely range, mean, standard error, phenotypic and genotypic variance and coefficient of variation. The phenotypic and genotypic variance and coefficient of variation were estimated according to the methods suggested by (Burton and Devane, 1953) as follows:

$\sigma^{2} \mathrm{~g}=(\mathrm{Mg}-\mathrm{Me}) / \mathrm{r}$

Where:

$\sigma^{2} p=$ Phenotypic variance

$\sigma^{2} g=$ Genotypic variance

$\sigma^{2} \mathrm{e}=$ Environmental (error) variance (Error mean square) 
$\mathrm{Mg}=$ mean square of genotypes

$\mathrm{Me}=$ mean square of error,

$r=$ Number of replication

Phenotypic coefficient of variation, $\mathrm{PCV}=(\sqrt{ }$ $\left.\sigma^{2} \mathrm{~g} / \mathrm{x}\right) \mathrm{x} 100$

Genotypic coefficient of variation, GCV $=(\sqrt{ }$ $\left.\sigma^{2} p / x\right) \times 100$

Where $\mathrm{x}=$ population mean

\section{Estimate of heritability}

Heritability $\left(\mathrm{H}^{2}\right)$ in broad sense for all characters was computed using the formula adopted by (Allard, 1960) as:

$H^{2}=\left(\sigma^{2} g / \sigma^{2} p\right) \times 100$

$\sigma^{2} p=\sigma^{2} g+=\sigma^{2} e$

Where:

$\sigma^{2} g=$ genotypic variance

$\sigma^{2} p=$ phenotypic variance

$\sigma^{2} \mathrm{e}=$ error variance

\section{Estimation of expected genetic advance}

Genetic advance (GA) for each character was computed using the formula adopted from (Johnson et al., 1955) and (Allard, 1960).

$\mathrm{GA}=(\mathrm{k})(\sigma \mathrm{p})^{*}\left(\mathrm{H}^{2}\right)$, and

$\mathrm{GA}($ as $\%$ of the mean $)=(\mathrm{GA} / \overline{\mathrm{x}}) \times 100$

Where, $\mathrm{k}=$ selection differential $(\mathrm{k}=2.06$ at $5 \%$ selection intensity)

$\sigma \mathrm{p}=$ phenotypic standard deviation
$\mathrm{H}^{2}=$ heritability (Broad sense)

$\overline{\mathrm{x}}=$ Grand mean

\section{Results and Discussion}

\section{Analysis of variance and genotypes mean performance}

\section{Yield related traits}

Mean squares of 7 traits of the four faba bean genotypes in the three environments (seasons) are shown in (Table 2). There were significant differences among genotypes, seasons and their interaction $(\mathrm{P} \leq 0.01)$ for most of the studied traits.

Results presented in (Table 3), showed highly significant differences for average number of days to $50 \%$ flowering, days to $90 \%$ maturity and plant height $(\mathrm{cm})$. The genotype Turkey was the earliest as it needs 97 days to reach maturity. On the other hand the two genotypes; Giza-843 and Otono were the latest as they required 109 and 112 days to mature, respectively.

The genotypes; Turkey and Giza-843 gave 20 and 13 pods per plant, respectively compared to the check SM-L (18), while Otono resulted in the lowest number of pods (8). The genotype Giza-843 gave the highest number of pods per plant (Table 4) which may be one of the factors contributing to its outstanding performance in seed yield. The highest number of seeds per pod was given by the genotype Otono and the check. Whereas, the genotype Turkey recorded the lowest number of seeds per pod.

\section{Seed yield and 100 - seed weight}

The results presented in (Table 4), showed the average 100 - seed weight (g) and seed yield $\left(\mathrm{kg} \mathrm{ha}{ }^{-1}\right)$. Significant differences were 
detected among the tested genotypes, season and their interactions for both characters. Also, (Waly and Abd El - Aal, 1986; Hanna, 1995; Salem, 1996); Abdel - Rahman, 2009 and Hassan, 2006) reported considerable variation among faba bean genotypes tested.

The three genotypes tested produced significantly heavier seed weight than the check. The heaviest seed weight was obtained by Turkey $(121 \mathrm{~g})$ followed by Otono (98 g) and Giza-843 (68 g.). The genotype Giza-843 gave seed yields better to the check and surpassed the check (SM - L) by $2.8 \%$, the other two genotypes; Turkey and Otono, which gave relatively seed yield $(3179 \mathrm{~kg} / \mathrm{ha})$ and $(2567 \mathrm{~kg} / \mathrm{ha})$, respectively less than the check.

Table.1 The pedigree of the four faba bean genotypes used in the study

\begin{tabular}{|l|l|l|}
\hline No. & Genotype & $\begin{array}{l}\text { Pedigree } \\
\text { (Single plant selection from introduced unknown source grown } \\
\text { at Dongola fields). }\end{array}$ \\
\hline 1 & Turkey & (BPL710×R.S.P.S line to Orobanche from Giza429) \\
\hline 2 & Giza -843 & (Introduced from Spain) \\
\hline 3 & Luz de Otono & (Released commercial variety) \\
\hline 4 & SM - L (check) & .
\end{tabular}

Table.2 Mean squares of yield and some yield components of 4 faba bean genotypes grown during three seasons 2013/14, 2014/15 and 2015/16

\begin{tabular}{|l|l|c|c|c|}
\hline Traits & Season $($ d.f = 2) & Genotype (d.f = 3) & Seas. X geno. (d.f = 6) & Pooled error $($ d.f = 18) \\
\hline Days to flowering & $101.694^{* * *}$ & $473.139^{* * *}$ & $41.583^{* * *}$ & 0.519 \\
\hline Days to maturity & $239.694^{* * * *}$ & $162.074^{* * *}$ & $5.657^{*}$ & 2.269 \\
\hline Plant height $(\mathbf{c m})$ & $533.581^{*}$ & $1110.585^{* * *}$ & $52.209 \mathrm{n} . \mathrm{s}$ & 60.243 \\
\hline No. of pods/ plant & $181.308^{* * *}$ & $251.249^{* * *}$ & $36.462^{*}$ & 19.353 \\
\hline No. of seeds/pod & $0.464 \mathrm{n} . \mathrm{s}$ & $4.606^{* * *}$ & $0.138 \mathrm{n} . \mathrm{s}$ & 0.142 \\
\hline 100-seed weight & $1427.111^{* * *}$ & $7400.407^{* * *}$ & $82.519^{*}$ & 29.509 \\
\hline Seed yield & $2409633.444^{*}$ & $143353.667^{* * *}$ & $111512.556^{*}$ & 44110.593 \\
\hline
\end{tabular}

$*$ and $* * *$ Significant at 0.05 and 0.001 levels of probability, respectively.

$\mathrm{n} . \mathrm{s}=$ non - significant difference at $5 \%$ probability level.

Table.3 Average performance for some Vegetative traits of 4 faba bean genotypes in the studies combined over three seasons

\begin{tabular}{|l|c|c|c|}
\hline Genotype & DF & DM & PH \\
\hline Turkey & 37 & 97 & 87 \\
\hline Giza - 843 & 43 & 109 & 102 \\
\hline Luz de Otono & 54 & 112 & 93 \\
\hline SM - L (check) & 46 & 104 & 112 \\
\hline Mean & 45 & 102 & 98 \\
\hline S.E \pm & $0.240^{* * *}$ & $0.502^{* * *}$ & $2.587^{* * *}$ \\
\hline C.V (\%) & 1.5 & 1.4 & 7.8 \\
\hline
\end{tabular}

DF: Days to $50 \%$ flowering, DM: Days to $90 \%$ maturity, PH: Plant height $(\mathrm{cm})$. *** Significant at 0.001 probability level. 
Table.4 Seed yield $\left(\mathrm{kg} \mathrm{ha}^{-1}\right)$ and its primary components of 4 faba bean genotypes in the studies combined over three seasons

\begin{tabular}{|l|c|c|c|c|}
\hline Genotype & SY & NPP & NSP & HSW \\
\hline Turkey & 3179 & 13 & 2.0 & 121 \\
\hline Giza - 843 & 3428 & 20 & 2.5 & 68 \\
\hline Luz de Otono & 2567 & 8 & 3.7 & 98 \\
\hline SM - L (check) & 3330 & 18 & 2.9 & 58 \\
\hline Mean & 3126 & 15 & 2.8 & 86 \\
\hline S.E \pm & $70.0^{* * *}$ & $1.466^{* * *}$ & $0.125^{* * *}$ & $1.810^{* * *}$ \\
\hline C.V $(\%)$ & 6.7 & 28.8 & 13.2 & 6.2 \\
\hline
\end{tabular}

SY: seed yield ( $\mathrm{kg} \mathrm{ha}^{-1}$ ), NPP: Number of pods per plant, NSP: Number of seeds per pod, HSW: hundred seed weight $(\mathrm{g})$.

*** Significant at 0.001 probability level.

Table.5 Estimation of genetic parameters for different quantitative traits in faba bean genotypes combined over three seasons 2013/14, 2014/15 and 2015/16

\begin{tabular}{|l|l|l|l|l|l|c|c|}
\hline \multicolumn{1}{|c|}{ Traits } & \multicolumn{1}{c|}{$\boldsymbol{\delta}^{\mathbf{2}} \mathbf{g}$} & \multicolumn{1}{c|}{$\boldsymbol{\delta}^{\mathbf{2}} \mathbf{p h}$} & $\mathbf{G C V}(\boldsymbol{\%})$ & $\mathbf{P C V}(\boldsymbol{\%})$ & $\mathbf{h}^{\mathbf{2}}(\boldsymbol{\%})$ & $\mathbf{G A}$ & GAM (\%) \\
\hline Flowering & 47.95 & 61.86 & 173.11 & 196.62 & 77.51 & 18.41 & 40.91 \\
\hline Maturity & 17.37 & 19.51 & 104.19 & 110.42 & 89.03 & 9.80 & 9.60 \\
\hline Plant height & 117.59 & 141.68 & 271.09 & 297.57 & 82.99 & 26.92 & 27.46 \\
\hline Pods / plant & 23.86 & 38.16 & 154.43 & 197.67 & 62.52 & 16.10 & 107.33 \\
\hline Seeds / pod & 0.496 & 0.557 & 17.60 & 18.65 & 89.04 & 1.62 & 57.85 \\
\hline 100-seed weight & 513.09 & 543.88 & 566.28 & 583.03 & 94.33 & 49.46 & 57.51 \\
\hline
\end{tabular}

$\delta^{2} \mathrm{~g}=$ Genotypic variance, $\delta^{2} \mathrm{ph}=$ Phenotypic variance, $\mathrm{PCV}=$ Phenotypic coefficient of variance, $\mathrm{GCV}=$ Genotypic coefficient of variance, $h^{2}(\%)=$ Broad sense heritability, $\mathrm{GA}=$ Genetic advance, GAM= Genetic advance as percent of mean.

Table.6 Correlation coefficients among studied traits of faba bean genotypes, combined over three seasons 2013/14, 2014/15 and 2015/16

\begin{tabular}{|r|l|l|l|l|l|l|}
\hline \multicolumn{1}{|c|}{ Traits } & Flowering & Maturity & Plant height & Pods/plant & Seeds/pod & $100-$ sw \\
\hline Maturity & $0.848^{* *}$ & & & & & \\
\hline Plant height & 0.211 & 0.251 & & & & \\
\hline Pods/plant & $-0.473^{*}$ & -0.146 & $0.679^{* *}$ & & & \\
\hline Seeds/pod & $0.997^{* *}$ & $0.810^{* *}$ & 0.193 & -0.511 & & \\
\hline 100 - sw & -0.269 & $-0.425^{*}$ & $-0.967^{* *}$ & $-0.707^{* *}$ & -0.235 & \\
\hline Seed yield & $-0.714^{* *}$ & $-0.438^{*}$ & $0.496^{*}$ & $0.950^{* *}$ & $-0.739^{* *}$ & $-0.480^{*}$ \\
\hline
\end{tabular}

* Significant at $\mathrm{p} \leq 0.05$ and $* *$ Significant at $\mathrm{p} \leq 0.01$.

\section{Genetic parameters}

Estimates of phenotypic and genotypic variances, phenotypic coefficient of variance, genotypic coefficient of variance, broad sense heritability $\left(\mathrm{h}^{2}\right)$, genetic advance and genetic advance as percent of mean are presented in Table 5. The phenotypic coefficients of variation $(\mathrm{PCV})$ were generally higher than the genotypic coefficients of variation $(\mathrm{GCV})$ 
for all traits studied, indicating more or less equal genetic effect on the trait. Here, the environmental effect is generally negligible, which is an agreenment with the observation of (Babar et al., 2002). Broad sense heritability $\left(\mathrm{h}^{2}\right)$ estimates were generally high to moderate for all of studied traits. The highest estimates of broad sense heritability was inscribed as $94.33 \%$ for 100 - seed weight, $89.04 \%$ for number of seeds per pod and $89.03 \%$ for days to $90 \%$ maturity. High estimates of heritability indicated that selection based on mean would be successful in improving these traits. The lowest value of $\left(h^{2}\right)$ was observed for number of pods per plant with $62.52 \%$. The moderate value of heritability for days to $50 \%$ flowering and seed yield were $77.52 \%$ and $76.48 \%$, respectively. In agreement with the results of this work, (Toker, 2004 ) recorded high to moderate heritability for traits containing days to flowering and seed yield and low heritability for number of pods per plant. The results of this research are also similar to the results of Bora et al., (1998), Kalia and Sood (2004) Alghamdi (2007) and Ibrahim (2010).

Number of pods per plant was recorded the highest genetic advance as percent of mean $107.33 \%$ followed by number of seeds per pod $57.85 \%$ and 100 - seed weight $57.51 \%$. The moderate genetic advance as percent of mean was recorded by days to $50 \%$ flowering $(40.91 \%)$ followed by seed yield $(31.87 \%)$. On the other hand, the days to $90 \%$ maturity recorded the lowest genetic advance as percent of mean.

\section{Correlation coefficient analysis}

Simple correlation coefficients among the examined characters are shown in Table 6 . Obtained liner relations among investigated characters (correlations) are insufficient in used faba bean genotypes in our research. However, Number of pods per plant could be useful selection criteria for this study because jointed or bilateral relations with this character have been given almost biggest value. Significant positive correlation values were detected between seed yield and number of pods per plant $\left(0.950^{* *}\right)$ and plant height (0. 0.496*). Similar results were also obtained by (Bora et al., 1998). There is strong association of these characters can be give importance during selection to improve the yield potential of the crop. While there are negative and highly significant phenotypic relationships for seed yield and seeds per pod, days to $50 \%$ flowering, hundred seed weight and days to $90 \%$ maturity. Positive and highly significant correlation was observed between number of seeds per pod and days to $50 \%$ flowering $(0.997 * *)$ and with days to $90 \%$ maturity $\left(0.810^{* *}\right)$. There is a negative but significant correlation was observed between 100 - seed weight and plant height ($0.967 * *)$, pods per plant $(-0.707 * *)$ and days to $90 \%$ maturity $\left(-0.425^{*}\right)$. Plant height had a positive and highly significant correlation with pods per plant $(0.679 * *)$. Days to $50 \%$ flowering had recorded positive and highly significant correlation with days to $90 \%$ maturity $\left(0.848^{* *}\right)$. Thus, correlation helps breeders to identify the characters that could be used as selection criteria in breeding programmed. These results suggested that improvement of grain yield in faba bean is linked with these traits (number of pods per plant and plant height) and selection of these traits might have good impact on yield.

The mean squares due to seasons were high significant for all traits studied except number of seeds per pod. Similarly, except the plant height and number of seeds per pod, the mean squares due to season $x$ genotype were significant for all traits. The mean squares due to genotypes were highly significant for seed yield, indicating existence of sufficient genetic variability for seed yield. Genotypic coefficient of variation (GCV) values were 
lower than phenotypic coefficient of variation (PCV) values for all the traits which reflect the influence of environment on the expression of traits. High genotypic coefficient of variation observed for 100 seed weight followed by plant height. High heritability estimates were recorded for $100-$ seed weight $(94.33 \%)$ and number of seeds per pod $(89.04 \%)$. The result of genetic advance as percent of mean an increase of $9.60 \%$ to $107.33 \%$ magnitude made by selection. Positive and highly significant correlation were observed for seed yield with number of pods per plant and plant height. So, it is concluded that these two traits may be considered as the selection criteria for the improvement of seed faba bean.

\section{References}

Abdelmula, A.A. (2002). The interrelationship between yield and yield components in faba bean (Vicia faba L.) under two water conditions. U. of K. J. Agric. Sci., 10(2): 180-196.

Abdel-Rahman, M. S. (2009). Inheritance of some growth and yield characteristic in new breeding lines on faba bean (Vicia faba L.). Ph.D. Thesis, Faculty of Agriculture, Assiut, Cairo, Egypt.

Alghamdi, S.S. (2007). Genetic Behavior of Some Selected Faba Bean Genotypes. African Crop Science Conference Proceedings. 8: 709-714.

Allard, R.W. (1960). Principles of plant breeding. John Wiley and Sons, New York.

Babar, M. A., M. A. Newaz and M. A. H. S. Jahan, (2002). Identification of selection parameters for yield improvement in french bean (phaseolus valgaris L.). Bangladesh J. Agri. Sci., 29 : 85- 89.

Bond. D, A. (1966). Yield and components of yield in diallel crosses between inbred lines of winter beans (Vicia faba). Journal of Agricultural Science of
Cambridge. 67: 335-336.

Bora, G.C., Gupta, S.N., Tomer, Y.S. and Singh, S. (1998). Genetic variability, correlation and path analysis in faba bean (Vicia faba L.). Indian J. Agric. Sci. 68(4):212-214.

Burton, G.W. and E.H. Devane, (1953). Estimating heritability in Tall Fescue (Festuca arundinacea) from replicated clonal material. Agronomy Journal, 45: 487-488.

De Pace C. (1979). Characteristics with significant correlation to seed yield and broad bean population grown in Southern Italy. In: Semi Current research on Vicia faba in Western Europe. Ed BABND, GR Scarascia Mugnozza and M.H. Poulsen, Pub. EECEUR, 6244 En., Luxembourg: 144167.

Dewey, D.R and Lu, K.H. (1959). A correlation and path coefficient analysis of components of crested wheat grass seed production. Agronomy J., 51 (9): 515: 518.

Duc, G. (1997). Faba bean (Vicia faba L.) Field Crops Res. 53:99 - 109.

Falconer, D.S. (1964). An introduction to quantitative genetics-Second edition. Oliver and Boyd Ltd., Edinburgh pp. 312-324.

FAO (2000). Production Year Book, Vol. 54, FAO, Rome.

Hanna, H. A. (1995). Studies on hard seed and other related characters of faba bean (Vicia faba L.) grown under Assiut conditions. M.Sc. Thesis, Faculty of Agriculture, Assiut, Cairo, Egypt.

Hassan, A. R. (2006). Performance of some faba bean (Vicia faba L.) genotypes under clay soil conditions in Assiut Governorate. Ph.D. Thesis, Faculty of Agriculture, Assiut, Cairo, Egypt.

Ibrahim, H.M. (2010). Heterosis, Combining Ability and Components of Genetic Variance in Faba Bean (Vicia faba L.). 
Meteorology, Environment and Arid Land Agriculture Environmental Science. 21(1): 35-50.

Johnson, H.W., Robinson, H.F., and Comstock, R.E. (1955). Genotypic and phenotypic correlations and their implication in selection. Agronomy Journal 47:477-483.

Kalia, P. and Sood, S.H. (2004). Genetic variation and association analysis for pod yield and other agronomic and quality characters in an Indian Himalayan collection of broad bean (Vicia faba L.). SABRAO Journal of Breeding and Genetics. 36(2): 55-61.

Salem, S.M. (1996). Effect of phosphorus fertilizers on yield and quality characteristics of faba bean (Vicia faba L.). M.Sc. Thesis, Faculty of Agriculture, Assiut, Cairo, Egypt.

Salih H. Salih, Osman A. Ageeb, Mohan C. Saxena and Mahmoud B. Solh (1995). Faba bean improvement. In production and improvement of cool-season food legumes in the Sudan, Salih H.S., O.A.A. Ageeb, M.C. Saxena and M.B. Solh. Edt. Nile Valley Regional
Program, ICARDA, Cairo, Egypt. Sindhu, J.S., O.P. Singh and K.P. Singh, (1985). Component analysis of the factors determining grain yield in faba bean (Vicia faba L.) FABIS News Letter ICARDA, Faba bean Information Service, 13:3-5. In Correlation and Path Coefficient Analysis of seed yield components in the Narbon Bean (Vicia narbonensis L.) Yucel et al., (2004) Turk. J. Agric., 28: 371-376.

Toker C. (2004). Estimates of broad-sense heritability for seed yield and yield criteria in faba bean (Vicia faba L.). Hereditas. 140: 222-225.

Way, E. A. and S. A. Abd El - Aal (1986). Combining ability for protein and cellulose content in a five-parents dialed of Vica faba L. FABIS Newsletter, 14: 4-6.

Witcombe, J. R. (1981). Genetic resources of faba bean. International conference on faba bean, Cairo 7-11 March 1981. In: Faba Bean Improvement. (Hawtin, G. and C. Webb, Eds.). p. 1. 1982 ICARDA. Netherlands.

\section{How to cite this article:}

Fatih E.A. Hamza. 2017. Performance Assessment, Genetic Variability, Heritability, Genetic Advance and Correlation Coefficient Analysis for Yield and Some Agro -Morphological Traits in Faba Bean (Vicia faba L.) Genotypes in the Northern State, Sudan. Int.J.Curr.Microbiol.App.Sci. 6(11): 1206-1214. doi: https://doi.org/10.20546/ijcmas.2017.611.143 